\title{
The Mediterranean Targeted Project MATER-a multiscale approach of the variability of a marine system-overview
}

\author{
A. Monaco ${ }^{a^{*}}$, and S. Peruzzi ${ }^{a, b}$ \\ ${ }^{a}$ CEFREM, CNRS UMR 5110, Université Perpignan, 52 avenue de Villeneuve, 66860 Perpignan Cedex, France \\ ${ }^{\mathrm{b}}$ Station Expérimentale d'Aquaculture IFREMER, chemin de Maguelone, 34250 Palavas-les-Flots, France \\ *: Corresponding author : Tel.: +33-4-68-66-20-88; fax: +33-4-68-66-17-13; email: monaco@univ-perp.fr
}

\begin{abstract}
The papers presented in this volume represent only a small part of the results obtained within the scope of the first integrated programme concerning the Mediterranean Sea. The latter is considered as a downscaled model of the ocean system, and a regional sea for the targeted projects supported by the European Commission.

Whatever the domain is, the variability of the system appeared as a major feature. Consequently, this theme has been selected, among the main initial objectives, as the central subject of this volume.

Spatial and temporal variabilities are considered, at different scales and at different (water, particles, sediment, trophic) levels of the marine ecosystem. In the hereafter contributions, one will find the longterm (millenar, secular and interannual), seasonal and short-term variability, the mesoscale and largescale processes and models, including coupled ecosystem models.

These results have to be considered as a significant contribution to a better understanding of the ocean as well as a base for a sustainable management of the marine systems. In effect, knowledge of the fundamental mechanisms and their variability are essential to create an efficient management of the environment.

As far as the forcing functions are considered, two main factors control the variability of the Mediterranean marine system: the climate-meteorology and, directly or indirectly, the anthropogenic activity, through the use of surface waters, soils, and air. These factors have an impact on the quality (biogeochemistry) of the environment and on the dynamics, thus influencing the biological level of the system.

As a result, the spatial distribution of the main wind trajectories, of runoff and rivers or straits, have a paramount influence on the observed characteristics of the various sub-basins and their gradients (north-south and west-east) over the entire basin.
\end{abstract}

Keywords: Marine system; Mediterranean; Variability; Pluridisciplinary; Climate 


\title{
The Mediterranean Targeted Project MATER - A multiscale approach of the variability of a marine system - Overview
}

\author{
A. Monaco ${ }^{a, *}$, S. Peruzzi ${ }^{\text {a,b }}$ \\ ${ }^{a}$ CEFREM ; CNRS-Université Perpignan, 52 avenue de Villeneuve, 66860 Perpignan Cedex, France \\ ${ }^{b}$ Station Expérimentale d'Aquaculture IFREMER, chemin de Maguelone, 34250 Palavas-les-Flots, France
}

\begin{abstract}
The papers presented in this volume represent only a small part of the results obtained within the scope of the first integrated programme concerning the Mediterranean Sea. The latter is considered as a downscaled model of the ocean system, and a regional sea for the targeted projects supported by the European Commission.

Whatever the domain is, the variability of the system appeared as a major feature. Consequently, this theme has been selected, among the main initial objectives, as the central subject of this volume.

Spatial and temporal variabilities are considered, at different scales and at different (water, particles, sediment, trophic) levels of the marine ecosystem. In the hereafter contributions, one will find the long term (millenar, secular and interannual), seasonal and short-term variability, the mesoscale and large scale processes and models, including coupled ecosystem models.

These results have to be considered as a significant contribution to a better understanding of the ocean as well as a base for a sustainable management of the marine systems. In effect, knowledge of the fundamental mechanisms and their variability are essential to create an efficient management of the environment.

As far as the forcing functions are considered, two main factors control the variability of the Mediterranean marine system : the climate-meteorology and directly or indirectly the anthropogenic activity, through the use of surface waters, soils, air. These factors have an impact on the quality (biogeochemistry) of the environment and on the dynamics, thus influencing the biological level of the system.

As a result, the spatial distribution of the main wind trajectories, of runoff and rivers or straits, have a paramount influence on the observed characteristics of the various subbasins and their gradients (north-south and west-east) over the entire basin.
\end{abstract}

Key words : Marine system, Mediterranean, variability, pluridisciplinary, climate

\section{Introduction}

MATER is the largest multidisciplinary research project supported by the European Commission, carried out within the framework of the Marine Sciences and Technology (MAST) and targeted projects on regional seas, especially Mediterranean Targeted Project (MTP). This second phase of the MTP (1996-1999) succeeds a pilot phase (1993-1996), by having for characteristic an integrated approach of the entire Mediterranean basin, in its physical, sedimentological, chemical and biological aspects.

* Corresponding author. Phone : 334686620 88. Fax : 334686617 13. E-mail: monaco@univ-perp.fr. A. Monaco was the coordinator of the MATER Project. 
The objectives of the project were as follows: -

- to study and quantify the triggering and controlling transfer processes of mass (water, particles, natural and anthropogenic, stable and radioactive elements) and energy between the different compartments (land-sea, sea-atmosphere, upper-deep waters, water-sediment, living-nonliving, pelagos-benthos) in contrasting environments (from eutrophic to oligotrophic)

- to appraise the time and space scales of the phenomena, in identified structures of the Mediterranean system

- to investigate the ecosystem response to these transfers.

The project offered the opportunity to study a system having the following characteristics:

- a semi-enclosed sea that allows the study, on a reduced scale, of processes typical of the world's oceans

- a laboratory for the examination of the complex interplay of natural processes that operate on a broad spectrum of spatial and temporal scales leading access to the variability of ocean systems

- the most nutrient impoverished large body of salt water

- a region of large-scale industrial and agricultural activity and the main recreational area in Europe.

MATER involved 54 institutions from 11 European countries (Belgium, Denmark, France, Germany, Greece, Italy, Norway, Spain, Switzerland, The Netherlands, United Kingdom) as well as Morocco and Tunisia, corresponding, on the whole, to more than 330 researchers and technicians.

The coordination of the programme was ensured by a scientific coordinator, a project manager and an EC officer. It also included a «Permanent Group» of 8 people, a Steering Committee of 15 people and an «Advisory Group» of 3 independent scientists. The Data Management was ensured by a Data Manager, with a «Data quality» group and three regional archiving centers operating in the three sub-basins.

\section{Strategies, methods and organisation}

MATER combined physical and ecological modelling with intensive field activity carried out in the three subbasins of the Mediterranean showing a progressive eastward gradient of oligotrophy: i) Western with emphasis on the Southern areas (Alboran and Algerian basins), ii) Adriatic/Ionian, and iii) Eastern, particularly the Aegean Sea.

The major strategies to study ecosystem dynamic included the following:

a) quasi-synoptic investigations on the main physical, biological and geochemical processes at subbasin and basin scale through two transmediterranean cruises performed at the beginning (MINOS) and the end (MATER cruise) of the programme

b) mesoscale surveys of dynamical features to couple the physical and biogeochemical studies

c) hydrological and nephelometric surveys to calculate horizontal fluxes

d) monitoring at representative sites of physical and biogeochemical parameters and the setup of observational stations of atmospheric inputs, to provide information at monthly, seasonal and interannual scales

e) surveys and monitoring of key zones like the Gibraltar, Sicily, Otranto and Cretan Arc straits

f) high resolution processes studies to determine the mechanisms controlling flux and pelagic/benthic coupling with examples of HFFE (high frequency flux experiment) in the NW Mediterranean and Alboran basin

g) numerical simulation of biogeochemical cycles 
h) modelling of the general circulation and its interannual variability, as well as implementing statistical tools and data assimilation

i) data analyses, model development and calibration to evaluate changes and trends of the Mediterranean ecosystem.

Besides classical techniques, equipment of high technology has been used during the course of the study. This includes the following : a) a completely new lander tripod built by NIOZ, which was initially tested in the Porcupine Abyssal Plain and the Benthic Banyuls Lander for in situ measurements of benthic activity and sediment diagenesis, b) innovative equipment from the Southampton Oceanographic Center such as the SeaSoar undulating towed CTD profiler and a prototype instrument measuring spectral light scattering absorption (SUMOSS) to investigate mesoscale activity, c) a Longhurst Hardy Plankton Recorder as well as Video Profiler from LPCM (Laboratoire de Physique et Chimie Marine, Villefranche-surmer) for investigating zooplankton and aggregate determinations, d) an ASIS buoy and onboard Microwave Systems to measure turbulent fluxes and the refractive index of the atmosphere, e) floats and transient tracer (CFCs, tritium, helium isotopes) sampling to extend hydrological observations and time series measurements of water masses and currents, f) moored and drifting sediment traps (PPS3 and PPS5) to quantify fluxes of major biogenic and abiogenic components and elements, g) a prototype of in situ large volume filtration pump (PERFIS by Technicap) using different type of adequate filters for diversified analyses of particulate matter and soluble elements, h) serial high pressure sampler to analyse the bacterial activity in the deep water column, i) USNEL and MultiCorers to assess the sediment/water interface and benthic activity, j) TOPEX/POSEIDON, ERS-1 and ERS-2 altimeter data sets along with the use of remote sensing and «composite methods» to analyse mean sea level variations and provide realistic representation of water circulation.

The programme also gave the opportunity to apply and compare different models at different scales and resolutions, as well as to develop new technologies in modelling and data analyses (e.g. isopycnal diffusion, isopycnal data analyses, assimilation techniques...). In this volume, the results of an innovative Model intercomparison experiment are presented (Beckers et $a l$.).

The size of the project and the integrated and multiscale approach required a matrixlike organisation (Fig 1) combining seven «Research Tasks (RT) or scientific topics, implemented through five «Workpackages» (WP) or operating strategies ; these later included either multidisciplinary field studies (WP 2, 3 and 4) carried out in the three Mediterranean sub-basins or modelling at various scales, but essentially basin scale oriented (WP1 and 5).

To date, a considerable amount of data has been collected notably during the field activity that covered 105 sea cruises, 1000 days at sea, 126 moored lines (current-meters, sediment traps, floats...), 270 stations where more than 100 parameters were recorded and more than 3500 CTD stations. The «MATER server» and regional web servers, the "MATER data base" can be used to access to the project information.

The data management structure included three regional archiving centers and two operational groups. The regional centers were (Fig. 1): the National Center for Marine Research in Athens (National Centre for Marine Research, Institute of Oceanography Hellenic National Oceanographic Data Centre, 16604 Hellinikon, Athens, Greece, e-mail: efstathios.balopoulos@hnodc.ncmr.gr), the Osservatorio Geofisico Sperimentale in Trieste (Borgo Grotta Gigante 42/c, 34010 Sgonico (TS), Italy) and the Ifremer/SISMER in Brest (TMSI/IDM/SISMER Centre IFREMER de Brest BP 70, 29280 Plouzanz, France, e-mail: sismer@ifremer.fr). A preliminary task has been to define a common protocol for data formatting and quality checking; this protocol has been improved during the period of MATER. The quality assurance and the safeguarding were improved by archiving and scientifically validating the data as soon as possible after their collection. This represents one of the first successful "distributed data base" for the oceanographic community. 
To meet a wide range of potential users, a preliminary version of the CD-ROM has been prepared and demonstrated during the project's final workshop in Perpignan (November, 1999). The final version is joined with the final scientific report (Maillard et al., this volume) and will be used by scientists and engineers for many years beyond the end of the programme. The Fig. 2, from this CD-ROM, gives an example of the numerous measurements performed during MATER project (here, 3141 CTD stations) ; their spatial distribution shows the most investigated areas of the programme.

\section{Figures 1 and 2}

This synthetic view presents outcomes that highlight the main achievements obtained during the three years of the MATER project. As already stated in its reports, the central outcome of the MATER programme remains the full approach of the variability (time and space) of the system, allowing a direct application of our investigations to global ocean studies and to the predictability of the Mediterranean evolution. This is demonstrated in three ways through examples taken from the different «workpackages»: the temporal variability (long-term, interannual, seasonal, short-term variability), the coupled biological-physical meso-scale processes, and modelling to simulate complex mechanisms at different time and space scales. This contribution is based on the results of the scientific activity first reported by the workpackage representatives in the MATER final report and refers to the contributions in this issue and to other recent publications on the subject.

\section{Temporal variability}

\subsection{Long-term variability}

As far as long term - at geological scale - changes are concerned, the most outstanding results were obtained through the study of cores collected in the Alboran Sea. Different biomarkers and micropaleontological proxies show a continuous record of the last 52,000 years, with an average temporal resolution of about 200 years. The good parallelism between these results and those obtained using $\mathrm{d} 18 \mathrm{O}$ records in Greenland ice cores, evidences this Mediterranean region as being very sensitive to a rapid climate changes and provide information of the possible connection mechanisms between the Alboran Sea and climate dynamics at high latitudes. The weakening in the global thermohaline circulation would force the southward displacement of the polar front allowing the entrance of the North Atlantic polar water through the Strait of Gibraltar during the Heinrich event (Cacho et al., in press ; Cacho et al., this volume).

Some natural radionuclides, such as ${ }^{210} \mathrm{~Pb}$ and ${ }^{7} \mathrm{Be}$ continuously introduced to the marine environment, as well as some artificial radionuclides such as ${ }^{90} \mathrm{Sr},{ }^{137} \mathrm{Cs}$ and ${ }^{239,240} \mathrm{Pu}$ present in the Mediterranean Sea since 1954 due to atmospheric nuclear fallout, were used to study and simulate long-term biogeochemical processes and their variability. A long-term box model for the Mediterranean has been developed to study soluble radionuclides ; subsequently, the 3D circulation model has been coupled with a 1D-biogeochemical model in order to understand today's distribution of non soluble ${ }^{239,240} \mathrm{Pu}$. The computed concentrations for ${ }^{137} \mathrm{Cs}$ and ${ }^{239,240} \mathrm{Pu}$ showed maxima corresponding to the weapons global fallout in 1963 and to the Chernobyl accident in 1986. Contaminant and radionuclide models have been used to predict the influence of anthropogenic activities in the marine ecosystem (Sanchez-Cabeza et al., this volume).

Long-term secular variability was also investigated using an Ocean General Circulation Model (OGCM) of intermediate resolution (the Mediterranean MOMA model) within the framework of a related EC programme dedicated to the study of the paleocirculation (CLIWAMP). Over 100 repeating years, the circulation remained stable 
under the flux forcing with little drift in water properties and no change in the circulation. A seasonal cycle was found in the Levantine Intermediate Water transport at Sicily and for Modified Atlantic Water at Gibraltar.

The same OGCM was used to model the thermohaline circulation during the last glacial maximum ; under the changed sea level and salinities, the model produces a strong buoyancy forced anti-estuarine circulation similar to the present day Mediterranean and significant local changes, including a complete shutdown in deep water formation in the Adriatic (Myers and Haines 2000; Myers and Haines, in press).

\subsection{Interannual variability}

In the last decade, the deep waters of the Mediterranean Sea are involved in multiannual trends which may be partly related to the changes in the thermohaline circulation in its eastern part (Roether et al., 1996 ; Theocharis et al. 1999). The reanalysis of the historical data and transient tracer data show that a massive formation of very dense water, namely Cretan Deep Water (CDW) occurred in the South Aegean Sea and that the most important source of the dense waters of the basin has switched from the Adriatic to the Aegean Sea (Lascaratos et al., 1999). This water occupied the deepest parts of the Eastern Mediterranean uplifting several hundred meters the older Eastern Mediterranean Deep and bottom waters (EMDW) of Adriatic origin. In the 1987-95, the Aegean started a deep water production at a much increased mean outflow rate of approximately $1 \mathrm{~Sv}$. The South Aegean is also a site of the Cretan Intermediate Water (CIW) formation that leads to ventilation of either the Levantine Intermediate Water (LIW) or the layers below it in the Eastern Mediterranean.

In this volume, Theocharis et al. describe the present status of the Eastern Mediterranean Transient (EMT) and its evolution since 1995, using hydrological and tracer data from 19971999. These authors underline that the entire bottom layer of the Levantine basin is now covered by the CDW and that in the Ionian, the CDW has reached the Straits of Otranto and Sicily.

A simulation and assessment of dense water formation processes was performed in association with the Eastern Mediterranean transient. A numerical model with a highresolution grid, using two different meteorological scenarios, represents conditions before and after 1987 when the first changes were observed. These experiments proved that the event could be explained as a response to interannual variability of atmosphere forcing. The very cold winters of 1987, 1992 and 1993 together with the extended dry period of 1989-1993 were identified as two main forcing mechanisms. The model was able to reproduce the effect of these dense waters on the thermohaline circulation of the Eastern Mediterranean (Lascaratos et al., 1999).

Identical multi-annual trends involving the whole water column are reported in the Adriatic Sea and which may be related to the recent changes in thermohaline circulation in the Ionian Sea and indeed the Eastern Mediterranean (Klein et al., 2000). Dense water of Adriatic origin resides between $1000-1500 \mathrm{~m}$, while the bottom layer is occupied by warmer and saltier water identified as Aegean water and spreading northwards. Therefore, a competitive mechanism from the intrusion of dense Aegean water into the Ionian Sea suggests a possibility of a new scheme for the Eastern Mediterranean's "conveyor belt" with possible consequences to the functioning of the Mediterranean ecosystem. As a consequence CFC, helium and tritium distributions showed the vertical water mass structure in the Adriatic as well as the Ionian Sea has changed. Other tracer data of CFC-12 and helium isotopes supports the idea that the deep waters had more old mid depth water mixed into it and that its replenishment was modest (Roether et al., 1998).

These interannual changes affected the biotic and abiotic parameters recorded in the South Adriatic, especially the primary productivity: the very considerable increase in productivity in March 1999 over that in March 1998 is consistent with the variation in vertical 
convection when in 1999 a greater near surface buoyancy flux and more intense upwelling was evidenced, a consequence of more intense winter climatic conditions.

The interannual variability of the Mediterranean Sea circulation was studied with a Ocean General Circulation Model (MERMAIDS, 1998). The model is forced with ECMWF 6-hour reanalysis data for the period of time January 1979 - December 1993 and COADS 1979-1993. Surface mean heat flux, already studied by Garrett et al. (1993), shows that there is significant interannual variability of wintertime heat flux during some of the years, common for the both parts of the basin. Relatively cold years over the whole Mediterranean are 1981, 1987 and 1991-1992. The time variability of the wind forcing in the Western Mediterranean (WM) is higher than in the Eastern Mediterranean (EM), with bigger winter maximums of wind stress and curl during almost all of the years. Due to the relatively strong meteorological forcing in winter, the basin mean kinetic energy distribution has a defined maximum every year in the period December-February. These maxima are strongest in years 1981, 1985, 1988 and 1992. The formation rates of some main Mediterranean water masses are related to wintertime surface cooling and convection. The WM deep water formation is biggest in 1981 ; in the EM they have three well defined maxima corresponding to years of strong winter cooling 1981, 1987 and 1992 (Demirov et al., this volume).

An interannual survey of particle fluxes and currents was performed in the Gulf of Lions over a 6-year period. Currents at mid-depth indicated flow direction in accordance with the cyclonic surface circulation of the Northern Current (NC) and downward particle fluxes showed a wide range of values, ranging from a few tens of $\mathrm{mg} \mathrm{m}^{-2} \mathrm{~d}^{-1}$ to more than $30 \mathrm{~g} \mathrm{~m}^{-2} \mathrm{~d}^{-}$

${ }^{1}$. The seasonal signal is correlated with the seasonal increase of the particulate inputs to the Gulf of Lions (river discharges, atmospheric deposition, biological production) and with the intensity of the oceanic transport processes (storms, fluctuations of the $\mathrm{NC}$, dense water cascading). Interannual monitoring allowed us to register a cascading of dense water during the 1999 winter which was characterised by an abrupt temperature drop on the slope $\left(1^{\circ}\right.$ at $1000 \mathrm{~m}$ depth) and an exceptionally high particulate flux during March and April. According to first comparisons with the surface wind stress and the heat fluxes, the event seemed to result from the cascading of cold water formed on the shelf. Re-analysis of historical data suggests that over the 1972-2000 period, four events of intense cascading of dense water from the Gulf of Lions shelf (in 1971, 1980, 1988 and 1999) contributed to the formation of Western deep water (Bethoux et al., this volume).

Long-term changes were also identified in the characteristics, structure and functioning of deep-sea benthic ecosystems explored at fixed deep sites (1540 and $950 \mathrm{~m})$ in the Cretan Sea from 1989 to 1998. Information was gathered notably on the inputs of primary organic matter to the bottom and the related biochemical composition of sedimentary organic matter. The results indicate the presence of large interannual variability of protein and RNA pools and it might be hypothesised that these processes occur on a large scale of the deep-sea Eastern Mediterranean in relation to the thermohaline climatic shift (Lampadariou and Tselepides, 1999)

\subsection{Seasonal variability}

The monitoring and the in situ observations of water mass flows, suspended matter, particle fluxes and biological activity during the three years of the MATER programme and in the three sub-basins, gave access to the seasonal variability of biotic and abiotic processes as well as of benthic response to column water changes (pelagos-benthos coupling). Studies in the Western Mediterranean (North and South), in the Adriatic/Ionian and the Aegean/Levantine basins provided clear examples of this temporal variability.

The first attempt to approach the overall system through the W-E gradient was performed during the first phase of the MTP programme. Particle fluxes measured by the "Euromarge" and "Pelagos" groups exhibited an obvious seasonal signal directly related to the 
Mediterranean climate, the functioning of the rivers and the geostrophic circuits (Heussner and Monaco, 1996). These results confirmed the "Ecomarge" France-JGOFS experiment carried out in the Gulf of Lions (Monaco et al., 1999).

Barale and Larkin (1998), using sea surface colour data, highlighted this seasonal variability and assosiated it with the impact of runoff from continental margin and vertical mixing due to the prevailing winds. Therefore, Barale and Zin (2000), confirmed that geomorphology and meteorology have an influence on both biogeochemistry and dynamics of the various sub-basins and of the entire Mediterranean region.

In the Adriatic, most of the measurements ran from 1997 to 1999 ; the field activity had, as a main target, the assessment of benthic response to organic carbon fluxes and nutrients as related to seasonal variability of the primary production, in accordance to the convective periods. The same trend is observed for all the biogeochemical parameters: light transmission, fluorescence, chlorophyll-a, POC, concentration of particulate matter, primary productivity, downward fluxes of biogenous constituents as well as inorganic elements (Boldrin et al., this volume). The coupling between the trend of total mass fluxes at the surface and bottom sediment traps, strongly suggests a rapid downward export of the particulate matter. A combined model (a coupled physical - biogeochemical water column model, ERSEM model and one dimensional version of POM) investigated the seasonal cycles (see part III).

Complementing previous works (Gacic et al., 1999 ; Giordani et al., 1992), Giordani et al. (this volume) report a yearly budget calculations of carbon and a depth dependence from the shelf station in the Northern Adriatic to the Ionian Sea. These results would have to be related with hydrographic and current measurements conducted during two consecutive winters in 1998 and 1999 in the Southern Adriatic, providing clues to the mechanisms of dense water formation from preconditioning to spreading phases ; the intensity of winter convection would control the interannual variability of low-passed water flux at the Otronto Strait (Manca et al., this volume).

The MATER programme was the first attempt of an integrated approach of the variability of pelagic-benthic coupling processes in the Aegean Sea; multidisciplinary results are presented by Lykousis et al. in this volume. The difference between the Northern and Southern parts reflects differences in sediment supply, particle transport and variable resuspension rates due to fine scale variability in the flow regime (Chronis et al., 2000). The lack of depth related patterns suggests that differences in organic matter quality between North and South are dependant upon the seasonal variation in primary productivity levels, whereas the spatial variability within regions emphasizes the role of local hydrographytopography in quantitative differences of organic matter. The N-S gradient is especially pronounced during winter-early spring. In the Northeast Aegean, a large part of the fixed carbon was channeled through the microbial food web towards copepods ; in contrast, there was a long low transfer of energy in the South Aegean where the multivorous food web was developed. Throughout the study area, almost $60-70 \%$ of autotrophic biomass and primary production was investigated by cells $<3 \mu \mathrm{m}$ (Siokou-Frangou et al., this volume).

The variations of oxygen consumption observed in the deep subbasins of the North suggest a significant import of organic matter. Besides the fact that the low values of nutrients, plankton biomass and production confirmed the oligotrophic character of the region (Ignatiades, 1998), high primary, bacterial and copepods production rates were detected in the area under influence of the Black Sea water mass. All results demonstrate that a microbial loop type of food web seemed to be evolving in all studied areas but the contribution of each compartment varied spatially and seasonally.

Furthermore, the total mass fluxes clearly marked the Northern and the Southern province with annual values of 514 to $1379 \mathrm{mg} \mathrm{m}^{-2} \mathrm{~d}^{-1}$ and 68 to $95 \mathrm{mg} \mathrm{m}^{-2} \mathrm{~d}^{-1}$ respectively. Settling particles showed a clear seasonal signal with high winter fluxes and low summer 
fluxes in the North. The opposite feature was observed in the South. This trend in carbon fluxes controls the structure, the size and the temporal variability of the meiobenthos and macrofaunal abundance, thus confirming the role of food availability on the benthic ecosystem (Tselepides et al., 1999 ; Lampadariou and Tselepides, 1999 ; Danovaro et al., 2000). The in situ measurements on Sediment Community Oxygen Consumption (SCOC), as an approximation for the mineralisation and supply of labile organic carbon in the sediment, lead to the same spatial difference between the two regions of the Aegean Sea (Duineveld et al., 1999).

The continental margin in the Western Mediterranean offers other examples of seasonal response of the benthic ecosystem through the SCOC which decreases with increasing depth and increases from winter to late spring.

In the Alboran Sea a complete seasonal cycle was monitored which revealed a strong relationship between surface productivity and particle fluxes for mid-depth waters (Fabres et al., this volume).

Benthic responses in relation to the different trophic conditions in several areas of the Mediterranean, namely the NW Western margin and the Cretan Sea were compared in term of temporal and spatial variability of the mass fluxes, pelagic-benthic coupling in organic matter composition, microbial response, meiofaunal changes and relative significance of bacteria (Danovaro et al., 1999) ; The authors reported clear seasonal changes in both areas ; nevertheless, the benthic components in the Cretan Sea, are subject to more limiting trophic conditions and so might have a higher efficiency in exploiting the particulate organic fluxes.

Box models were developed to study the seasonal cycle and trophic regime of the Mediterranean ecosystem. The oligotrophy and the gradient explanation were obtained on the basis of an NPD (Nutrients nitrogen and phosphorus, Phytoplankton and Detritus) model, underlining the importance of the detritus sinking. Flow analysis approaches suggest that even in oligotrophic environments where picoplankton dominates the primary production, netplankton is the main responsible of sinking particulate matter and, thus of the benthic response. A more appropriate ecosystem model taking into account microbial processes will be used (see part III).

\subsection{Short-term variability}

Two original experiments on short-term variability of particle flux (HFFE) were performed in two areas of the Western Mediterranean, the Gulf of Lions and the Alboran Sea. The Gulf of Lions experiment took place in spring 1997, at a local scale (tens of kms), SouthEast off the Rhône river. Concerning the dynamics of water masses, high inertial and low frequency variabilities were observed at all depths, from $250 \mathrm{~m}$ to $1200 \mathrm{~m}$. The site was embedded in a region where intense meandering of the Northern Current has occurred, which determines a shelf/slope density front ; this front showed dramatic vertical migrations of more than $100 \mathrm{~m}$ between one-week interval hydrographic casts. Meandering patterns of shorter wavelengths appeared which could be associated to eddy-like motions induced by baroclinic instability mechanisms and could be responsible for the sub-mesoscale activity (Flexas et al. this volume). The variability of the deep currents is dominated by a 7-day period fluctuation and would have a significant impact in the export of matter off the shelf ; the 7-day period current fluctuation probably corresponds to a propagating topographic wave, whose period is close to the 8-day period wave reported by Millot (1985).

Regarding particle fluxes, the situation reflects the complexity of hydrodynamical conditions. Total mass fluxes measured over periods of a few days covered a wide range of values from less than a few $\mathrm{mg} \mathrm{m}^{-2} \mathrm{~d}^{-1}$ to several grams. The results will probably require sophisticated data reduction and modelling before being fully understood. Nevertheless, the HFFE experiment offered the opportunity to relate organic carbon fluxes with small-scale variability of bacterial and phytoplankton production (Diaz et al., 2000). The comparison of 
primary production with measured or estimated fates of organic matter shows that the carbon balance was never reached (Van Wambeke et al., this volume) at this scale.

Another High Frequency Flux Experiment was carried out in the Alboran Sea for one month and with a 3-days sampling interval ; it was associated with biological and biochemical measurements during cruises. The biomass and production measurements confirm that the high hydrodynamism of the Alboran Sea effectively translates onto enhanced planktonic biomass, activity and particle fluxes. Noticeable changes in phytoplankton, bacterial, microheterotroph and zooplankton biomass and production rates were observed at a timescale of days in the Northern part of the Western Alboran Gyre. During the spring 1998 cruise, a nutrient upwelling event occurred causing a subsurface phytoplankton bloom and increased production rates up to $1 \mathrm{gC} \mathrm{m}^{-2} \mathrm{~d}^{-1}$; it was recorded and followed at depth. Similarly, the photosynthetic production of total (TOC), particulate (POC) and dissolved (DOC) organic carbon showed a short-term variability at all explored sites (Fabres et al., this volume).

\section{Temporal \& spatial meso-scale variability}

Between 1993 and 1997 meso-scale waters were seasonally investigated in different areas of the Mediterranean Sea: the north-Western margin, the Western Adriatic to the Strait of Otranto and the Southern (Cretan) and Northern Aegean Sea. Concerning the suspended particulate matter, systematically analysed during the different phases of the MTP, Price et al (1999) discussed the spatial and temporal variability of its distribution and composition. Besides the prominent role of the hydrological structures and water dynamics, especially dynamic eddies that affect the precipitation of certain elements in the SPM. Changes in the composition of the SPM have been used to decipher their source and dispersal. For instance i) the pattern of particulate $\mathrm{Al}$ within the Adriatic and at the NW margin relates to the riverine influences but also to bottom sediment resuspension, ii) Mn appears to be an even more reliable indicator of riverine supply, iii) the patterns of $\mathrm{P}_{\text {org }}, \mathrm{Si}_{\text {bio, }}, \mathrm{Ba}$ ex and, with a less extend, POC are mainly associated with biological production.

Several experiments performed in the Western Mediterranean revealed some unprecedented aspects of the general circulation at mid-depth in the Algerian Basin at meso, submeso and large scales. In particular, work within MATER has for the first time clearly identified subsurface submesoscale coherent vortices and a large scale gyre cyclonic circulation associated with the slow cyclonic migration of large Algerian anticyclonic eddies. Mesoscale structures have been observed since the eighties (Taupier-Letage and Millot, 1988) and can last many months or even years. One of the possible processes at mesoscale is the interaction between large open sea eddies in the Algerian and Levantine Intermediate Waters. These anticyclonic eddies are generated by destabilisation of the Algerian current and propagate eastward along the slope and then, at the entrance of the Sardinia channel, become detached from the coast and become open sea eddies. The CTD data recently gathered allows for a detailed analysis of the thermohaline structure of the mesoscale Algerian eddies to be made, and to show how interaction between the eddies and the filaments affects the intensity of the small-scale mixing processes.

Along with large-scale structures, it is clearly of interest to improve the coupled physical-biogeochemical models at the level of mesoscale structures. In effect, the Mediterranean Sea is known to be mostly oligotrophic, although some regions where mesoscale dynamics occur are characterised by high levels of primary production. These structures are common and multi-scale and multi-disciplinary approaches to understand them constituted a major outcome of the MATER programme. Monitoring by surface drifters coupled with satellite infrared imagery and CTD, ADCP measurements during the Algers '96 and '98 cruises, allowed one to document different stages of their motion. In particular, during the Algers '96 the use of in situ measurements, the westward drift of an anticyclonic open-sea 
eddy (100-200km diameter) was followed and tracked and showed a movement of 2-3 km/day with swirl velocities up to $50 \mathrm{~cm} / \mathrm{s}$, at a mean orbital period of 7 days. This was characterised for its entire depth down to $2800 \mathrm{~m}$ (Ruiz et al., this volume).

The Elisa experiment (Eddies and Leddies Interdisciplinary Study off Algeria) was another very important contribution to the analysis of the biological response to mesoscale activity, one of the main objectives of the MATER project i.e. the origin of the oligotrophy of the Mediterranean sea (Taupier-Letage et al., 1999). In the Algerian basin, a key area for understanding dynamical and biogeochemical functioning in the Mediterranean, two Algerian Eddies (AE) were tracked with satellite images during their anticlockwise circuit, in 19971998. The associated biological response was analysed using hydrodynamical structure and observations of chlorophyll and nitrate concentration. AE represent very oligotrophic areas in summer ; in spring, open-sea AE undergo strong winter mixing with maximum downward velocities and corresponding maximum integrated chlorophyll concentrations. An important export of organic matter is associated with $\mathrm{AE}$ which is marked by a nitrate maximum and oxygen minimum between 300-600m ; this enriched layer cannot exit through the Gibraltar Straits and hence nitrate is trapped within the Mediterranean. Therefore, it is hypothesized that the enhanced mesoscale biological activity connected to the instability of the Algerian current might be one reason for the gradient of oligotrophy from the Western to the Eastern Mediterranean.

One of the possible processes enhancing the export of organic matter could be the formation of large aggregates. Using an Underwater Video Profiler, Gorsky et al. (2000) relate the vertical distribution of large particulate matter (LPM) with mesoscale physical structures and biological activity ; they have estimated that up to one third of the particulate matter pool might be composed of large particles.

Finally, the importance of mesoscale processes for primary production predictions was examined through different process studies, including the spring bloom after deep winter convection in the NW Mediterranean; the fertilising effect of a front (Almeria Oran front) and the role of large eddies in the Algerian current. The observation and modelling at an adequate high resolution is a key aspect for progress in understanding the physical-biological coupling. At the beginning of MATER, two biological models already existed, but a new version has been developed which takes into account additional parameters. Concerning the spring bloom, the mesoscale heterogeneity of the mixed-layer depth is responsible for the mesoscale variability of primary production. A primary production model, embedded in a threedimensional primitive equation model with explicit mixed-layer physics shows that: i) due to the spatial and temporal heterogeneity, instantaneous primary production can be underestimated by a factor of four, and ii) the spring bloom is extremely sensitive to wind bursts. For the importance of a front and eddies, a 3D modelling approach was used which coupled the ocean dynamics and the biological activity (nitrate, ammonium, phytoplankton, zooplankton, detritus and dissolved organic matter) (Levy et al., 1998 ; Loukos et al., 1999 ; Olivier and Memery, 1999).

\section{Large scale processes and models}

\subsection{Water mass circulation}

There are well known dynamical processes in the Mediterranean Sea general circulation that may be studied in order to understand their variability and to parametrise them within the large scale ocean numerical models (Pinardi and Mosetti, 2000). In the MATER project, the processes considered by this approach are: i) deep water overflow and spreading, ii) Algerian current instabilities, iii) bottom topography interaction with eddies, and iv) vertical mixing parametrisations for shallow and deep convection events. The regional modelling concentrated in two regions, the Gibraltar and the Sicily Straits ; these regions were 
examined with high resolution numerical models in order to better represent dynamical balances and to look at selected processes which are known to occur in each region.

Furthermore, advanced data assimilation tools were developed which gave the best estimate of the flow field from observations within the constraint of the model equations. The assimilated data sets prepared by the project are of major importance to assess the spatial and temporal structure of the seasonal and interannual variability of the general circulation (Pinardi et al., 1997).

The structure and the variability of the general circulation was studied from satellite remote sensing and for the first time oceanographers have benefited of appropriate altimeter data for analysing the mean sea level and surface circulation variations (Benkiran et al., 1997) ; the seasonal and interannual signals were revealed by the analysis of Topex/Poseidon and ERS-1/2 data. The results suggest that mass in the Mediterranean is not conserved at the seasonal scale and that there is significant interannual variability. The surface circulation is characterised by a large range of spatial and temporal scales which is well approached by combining T/P and ERS-1/2 data and shows a strengthening of cyclonic Western circulation in winter, and a strengthening of anticyclonic Alboran and Ierapetra gyres in summer and fall. The mean sea level seasonal cycle is quite similar in the Western and Eastern basins and drift, from 1995, of about 7-8 mm/year, with a different trend in the Western and Eastern part, i.e. 4-5 and 8-9 mm/year respectively (Larnicol et al., 1995). In the paper presented in this volume, a longer period of observation (1993-1999) allows Larnicol et al., to distinguish two categories of eddies; eddies which exhibit a stable position and a relative coherent variability and eddies that are characterised by a high spatial and temporal variability and which corresponds to the transient mesoscale activity of a current.

The functioning of the circulation of the Mediterranean Sea was also investigated by the analysis and modelling of transient tracers (CFCs). The Mediterranean MOMA model is capable of producing deep water with realistic CFC-12 concentrations: the old circulation state of the Eastern Mediterranean with one source of deep water from the Adriatic is represented quite well as is the exchange through the strait of Sicily and the production of Levantine Intermediate Water (LIW) (of $\sim 1.0 \mathrm{~Sv}$ ), in good agreement with observations. The model simulation combining different climatologies confirmed the important role of LIW on the formation of deep water in the Adriatic (Klein et al., 1999). The comparison of salt inventories for 1987 and 1995 indicates an apparent increase in salt content of $5.710^{13} \mathrm{~kg}$ and links between intermediate and deep water masses on a sub-basin scale (Klein et al., 1999) In the Western basin, intermediate and deep circulation were monitored by Lagrangian floats in the years 1997 and 1999. The results suggest a somewhat higher eddy activity in the Western part of the Provençal basin where cyclonic eddies dominate over anticyclonic ones. Profile data reveal a strong signature of the warm Levantine Water varying with time. The deep floats offer an unprecedented view of the deep circulation and areas of water mass formation at a time scale of weeks to months. Numerical simulations of Lagrangian trajectories, computed in an OGCM, are qualitatively consistent with the large scale events as seen by drifters (Testor et al., 1999).

The new data set of hydrographic tracers (CFCs, helium, tritium), ADCP and float experiment show that the Tyrrhenian basin is exporting a deep water mass (Tyrrhenian Deep Water, TDW) into the Algero-Provençal basin at depths below the LIW ; the TDW flow was estimated to be $0.4 \mathrm{~Sv}$. This transport is comparable to the deep water formation rate observed in the Gulf of Lions. The float trajectories exhibit noteworthy features including strong exchanges between the sub-basins, across boundary currents and in areas of strong eddy activity (Reich and Send, 1999). Send et al. (1999) indicated the forcing factors for seasonal and interannual variability and showed the importance of the surface fluxes which drive much of the system and their relation to large-scale phenomena like the NAO.

The monitoring and numerical experiment performed in the Balearic Channels confirm the existence of a close link between the north-south transport and the atmospheric conditions 
characteristic of severe winters when winter intermediate water forms. These results point to the existence of a new and challenging example of how local or regional thermodynamic processes can affect and modify the large scale circulation (Riera et al., 1999).

A comparison of model simulation and assimilation experiments demonstrated that the simulation is not able to correctly reproduce some small-scale dynamical features like Ierapetra gyre and underestimates the circulation in the Mersa-Matruh gyre in the Levantine basin. Therefore, we can say that the data assimilation procedure implemented during MATER is good provided that a multivariate method can be used. The objectives were focused on the predictability of the circulation at two scales: I) general circulation, and its seasonal and interannual variability, and ii) mesoscale eddies and meanders and sub-basin scale gyres response to wind. A fifteen year Mediterranean Sea circulation was modelled with the GFDL primitive equation model. The surface forcing was computed from ECMWF high frequency reanalysis data for the period of time from 1979 to 1993, and the model was run with interactive air-sea fluxes. In this volume, Demirov et al. distinguished two periods (1981-1987 and 1988-1993) and confirm, from wind and heat anomalies analyses, that the Mediterranean changed dramatically between the two periods and that these modifications were produced by decadal changes related to NAO.

Taking into account the importance of the wind stress and for the main goal to provide improved forcing terms (radiative, heat and momentum fluxes) usable for physical analysis and modelling, a FETCH experiment was carried out in the Gulf of Lions during March-April 1998. Measurements of atmospheric parameters, hydrology, drag coefficients on two platforms (ATALANTE ship and ASIS buoy), multiple flights with airplanes, ERS and T/P images were used to improve the parametrization of the air/sea exchange processes and to study the behaviour of the oceanic mixed layer forced by strong off-shore winds. The experiment gave the opportunity to use, only for the second time, a sonic anemometer for turbulent flux measurements at sea. Results show that care must be taken for the measurement and analysis technique of turbulent fluxes. Analysis of the latter provided by atmospheric circulation models shows that a large bias can be obtained when using model estimates. None of the modelled radiative fluxes could be successfully compared with the ship observations, whereas downward solar fluxes from satellite data gave quite good agreements with local observations (Hauser et al., 1998 ; Dupuis et al., 1999).

As far as the whole Mediterranean basin is concerned, its straits and passages become crucial and play an important role in triggering the circulation through mass transport exchanges (Astraldi et al., 1999). Emphasis has been devoted to the Sicily strait governing the exchanges between the Western and Eastern Mediterranean and here a three-layer model has been implemented. For realistic values of transport, the model illustrates the scenarios of seasonal variability. Sensitivity experiments carried out with different boundary fluxes have created interesting features of the bifurcation of Modified Atlantic Water and the importance of flux of Levantine Intermediate Water. In order to accurately represent the bathymetry which greatly controls the communication between basins, an efficient interactive procedure was achieved (Pierini et al., 1997). In this part of the Central Mediterranean (Sicily, Sardinia and Tunisia triangle) new data has demonstrated that patterns in chemical parameters (oxygen and nutrients) of water masses are highly consistent with $\varnothing$-S signatures and that the intermediate layers were subject to a quite high internal variability (Astraldi et al., this volume).

The Otranto strait exemplified our interest to monitor the water exchanges, to better understand general circulation changes and multi-scale temporal variability (Gacic et al., 1996). Current measurements at the bottom of this strait evidence the outflow of the Adriatic Dense Water (ADW) as a vein in the range 0.1-0.4 Sv, reaching its maximum during postconvection periods while it is reduced during the pre-conditioning phases. This was explained in terms of the seasonal filling-up/emptying of the ADW reservoir in the Southern Adriatic. Interannual variability is of the same order of magnitude as seasonal variation and it is 
determined by the intensity of the vertical convection and the deep water formation processes. Superimposed on this low-frequency variations are the sub-inertial variations from weekly to monthly time scales that can generate transient bottom water outflow rates by almost $1 \mathrm{~Sv}$, with some reversals of a duration up to one week.

Long term measurements carried out in the Corsica Channel definitively confirm that the seasonal signal represents a stable component of the Corsica current. They also indicate the importance of interannual variability and the influence of the large scale atmospheric systems, namely the North Atlantic Oscillation (NAO) which alternatively drives cold and warm and wet air masses, thus modulating the intensity of air-sea exchanges (Astraldi et al., 1999). The variable intensity of the annual ventilation of the bottom part of the Western Mediterranean might be the final consequence of this process.

In contrast to previous models for the general circulation of the Mediterranean Sea (EROS 2000, EUROMODEL, MERMAIDS, POM, OPA, GFDL) most models adopted by MATER use a $1 / 8^{\circ}$ scale (Myers \& Haines, 2000 ; Demirov \& Pinardi, this volume) and emphasise interannual variations rather than seasonal cycles. The paper presented by Beckers et al. in this volume is a synthesis of the MEDMEX experiment aiming at promoting model intercomparison, in order to provide the most sensitive parameters one could expect for the different models and for realistic forcing. All models provided a satisfactory representation of the seasonal cycle of the circulation, thus giving some confidence of the model responses at this scale. The authors pose the question to which extent the interannual variability may be assessed with the models without data assimilation.

\subsection{Ecosystem studies}

The ecosystem studies focused on the development and application of coupled hydrodynamical/biogeochemical models in the Mediterranean Sea and its sub-basins (Crise et al., 1999). The Mediterranean is mostly oligotrophic and consequently dominated by the transfer of energy through the microbial loop ; both nitrogen and phosphorus have been shown to be potentially limiting nutrients for phytoplankton and bacterial growth (Bethoux et al., 1992 ; Thingstad and Rassoulzadegan, 1995). Thus, a multi-nutrient ecosystem model has been designed to describe phytoplankton processes and nutrient cycling. The 3-D hydrodynamical models used were MOM3D (Modular Ocean Model) coupled to NPD and NPDZ aggregated ecosystem model for the basin-wide simulations and POM3D (Princeton Ocean Model) coupled to ERSEM (European Regional Seas Ecosystem Model) for the subbasin simulation (Baretta-Bekker et al., 1997). A modified version of the 1D coupled physical - biogeochemical water column model described by Allen et al. (1998) was used to simulate primary and bacterial production.

The three dimensional eco-hydrodynamical model was developed to reproduce, at basin scale, the dynamics of the first trophic level under a potential multinutrient limitation (Allen et al. this volume ; Crispi et al., this volume). The results that have emerged are : i) the nutrient input in the surface waters from the Atlantic through Gibraltar is zonally transported by an inverse estuarine circulation, ii) nutrient depletion of the euphotic zone by the sinking of organic matter maintains the west-east trophic gradient and the nutrient distribution is zonally affected by permanent cyclonic gyres, iii) the trophic meridional gradient is also sustained by the coastal upwelling induced by the prevailing wind regime in some areas located along the northern boundaries of the two sub-basins, iv) the seasonal variability in nutrient availability in the euphotic zone is strongly dependent on the amount of wind-driven turbulent entrainment of water from below the nutricline, clearly introducing winter chlorophyll maxima in the Western part and spring maxima in the Eastern Mediterranean, v) advection/diffusion processes deeply rework the distribution of such nutrients supply throughout the basin and laterally convey the biological signal along the major pathways determined by the Mediterranean general circulation. In conclusion, basin-wide simulations 
with the aggregated 3D-ecosystem model show the observed west-east gradients in $\mathrm{N}$ and $\mathrm{P}$ concentrations, as well as the north-south gradients, which indicate that the major mechanisms causing these gradients are properly represented.

A more quasi-synoptic investigation of the entire basin during the MINOS cruise (Mediterranean INvestigation of Oligotrophic Systems), well reconstructed the decrease of integrated primary production, particulate carbon export and nutrient availability towards the eastern part of the basin. The sustaining of $90-95 \%$ of primary production by internal recycling of organic matter and the limitation of production by phosphate were advocated (Moutin and Raimbault, this volume). A second transmediterranean cruise was undertaken three years later following almost the same east-west transect (Lykousis et al., 1999). Turley et al. (2000) demonstrated that the relationship between bacterial and primary production in the two basins are significantly different.

At the level of the benthic microbial system, the highest values of bacterial respiration rates in the near bottom waters were recorded in the areas characterised by the highest fluxes of particulate organic carbon. Conversely, the lowest respiration rates were measured in the most oligotrophic zone of the Mediterranean. At the scale of the entire Mediterranean basin, benthic microbial populations appear as important agents of the early diagenesis processes and a link between pelagic and benthic systems. Comparison of the mineralisation rates of organic material measured in the benthic system with those obtained in the corresponding water column should allow one to determine the relative importance of pelagic and benthic bacteria in the remineralisation processes throughout the whole oceanic system (Giordani et al, this vol., Tholosan and Bianchi, in press).

A biomass-based ecological model was developed for the Adriatic Sea to investigate the relations and interactions between physical and biogeochemical processes occurring in this sub-basin environment at seasonal time scales (Zavatarelli et al., 2000). The simulation results highlight the role of the physical processes in determining and maintaining some of the nutrient and phytoplankton biomass distribution and characteristics in the Adriatic. Furthermore, the characteristics of the phytoplankton seasonal cycle have been found to depend, in order of priority, on the river-born nutrient input and physical horizontal and vertical processes which respectively dominate the shallow and open sea conditions in the Adriatic Sea.

\subsection{General evolution of the Mediterranean ecosystem}

An analysis of the evolution of marine characteristics by data acquisition and by historical data analysis was performed to describe and forecast the climatic environmental changes of the Mediterranean. The presented work takes into account known hydrographic changes that have occurred during the last decades.

During the MATER project, Béthoux et al. (1990) confirmed the warming trend in the Western Mediterranean deep water; for the period 1959-1997 the temperature and salinity changes amount to $0.13^{\circ}$ and 0.04psu respectively (Béthoux and Gentili, 1997). These authors calculated change in radiative forcing between 1940 and 1995 over the Mediterranean and compared it with that for the Northern hemisphere during the same period. The most interesting conclusion is that the trend of increasing temperature observed in the Mediterranean constitutes the first measured effect of the Green House Effect change. The calculated changes in heat and freshwater budgets appear sufficient to explain the dramatic change in water mass formation and distribution in the Eastern Mediterranean (DellaVedova et al., 1995; Roether et al., 1996).

This new assessment of forcing on the circulation allows for the quantification of deepwater fluxes and vertical mixing in the eastern basin. These are different and higher than those proposed in previous studies. In order to reproduce the salinity and chloro-fluorocarbon evolution in both western and eastern basin since 1960, the model includes the following 
circulation changes: i) a higher transfer of the deepwater formed into the Aegean Sea towards the deep Ionian Sea and also towards the deep Levantine basin, ii) a formation of deep Levantine water which is commonly known to form only intermediate water flowing directly towards the Western basin, iii) an intensive upwelling in the Ionian Sea and in the Levantine basin of water located between 500 and 1000m (Lascaratos et al., 1999).

The model also represents a tool to simulate modifications linked to modern anthropogenic perturbations and to provide new constraints for the $3 \mathrm{D}$ circulation and biogeochemical cycle models. These evaluated circulation changes may have an impact on nutrients, oxygen and carbon budget and consequently may affect the whole Mediterranean ecosystem.

Long-term records of ecosystem evolution are scarce ; Duarte et al. (1999) look at the long-lived organisms, for instance Posidonia oceanica and Pinna nobilis, which have the potential to discriminate decadal scale changes in the Mediterranean ecosystem. The authors advice to establish a coherent system of observation from local to meso-scale to basin-scale.

\section{Conclusion}

The Mediterranean Sea clearly appears as a downscaled model for the study of ocean circulation and a test zone for the climatic changes. The MATER research greatly improves the knowledge of its variability at many and different spatial and temporal scales and of the coupling between physical, biogeochemical and ecological systems. This represent the most important research topics that oceanographers and environmental researchers are currently facing. Reasonably, Zavatarelli (1999) points out how the Mediterranean Sea should be treated as a unique system for environmental management and illustrates the importance of studies on the variability of natural systems for policy making. He emphasises that this variability determines the range of options to be adopted in establishing an environmental management policy devoted to preserve the environment while at the same time producing social and economic benefits. For Turley (1999) "the future of the Mediterranean ecosystem does not look rosy" ; she recommends that scientists, economists and policy makers from the 18 countries bordering the Mediterranean must interface in order to ensure an appropriate response.

The Mediterranean Sea, now considered by public opinion, science and the authorities as an ecosystem, has to be studied and managed globally as well as locally ; this should led to the federal concept of "sustainable development" which requires, after Valette (1999) "spatial integration of the research and management of all the system across the complete spectrum of scales as well as time integration at different scales in economic analyses.

\section{Acknowledgements}

We would like initially to thank all the participants in the MATER program, for the confidence and friendship that they granted to us in the difficult task of coordination and scientific animation. In spite of the difficulties related to its size, the project had a very significant audience and visibility and this volume reflects the efforts of an individual and collective work over more than three years.

Even if it is incomplete compared to the enormous mass of results, we are extremely grateful to the authors who agreed to quickly publish their work to be used as a basis for other scientific communities which will be working in the Mediterranean. We are confident that the results of MATER will be the subject of many other publications for several years to come. A very special thank goes to Elisabeth Lipiatou, scientific officer of the program, who followed, encouraged and lived the program more closely to the researchers. We owe her all a deep 
recognition for her scientific and human qualities. A very active role was played by the Workpackage leaders: organization of the campaigns, workshops, advanced courses, collection and drafting of the annual scientific reports for the European Commission. For this reason, the majority of these people are the guest editors of this volume. A very active role was also played by the Research task leaders at the time of the second annual report. In this overview, we made use of these internal reports, some individual contributions as well as the published articles and manuscripts of this volume. We asked for a critical review on both the biogeochemical and the physical-modeling aspects. We are particularly grateful to N.B. Price and J.M. Beckers for their accurate revision and critical discussion. The authors thank the SAFEGE - CETIIS'staff with Pierre-Marie Lehucher as Project manager ; in particular we gratefully acknowledge Laure Beautier for the overwhelming task of administrating such a large project.

Others deserving recognition include Catherine Maillard, in charge of the Data Management at Ifremer, Bruno Manca and E. Balopoulos from the National Center of Data Management in Trieste and Athens respectively. The CD Rom included in this volume is the expression of the significant task that constituted the collection and handling of extremely numerous and multi-disciplinary data sets. Bruno Charrière largely contributed to the realization of this volume; he is a scientist of quality which agreed to perform the task of gathering the documents and ensuring the communication among the various authors. We are especially grateful for his devoted effort, but many are those who will find him in the ADIOS program which just started. This paper is a contribution to the MTP II - MATER project (MAS3-CT 96 - 0051). 


\section{References}

Allen, J.I., Blackford, J.C. and Radford, P.J., 1998. A 1-D vertically resolved modelling study of the ecosystem dynamics of the middle and southern Adriatic Sea. J. Mar. Sys., 18: 265286.

Allen, J. I., Sommerfield, P. J. and SIiddorn, J., 2001. Primary and baterial production in the Mediterranean Sea: a modelling study. J. Mar. Syst., this volume.

Astraldi, M., Balopoulos, S., Candela, J., Font, J., Gacic, M., Gasparini, G.P., Manca, B., Teocharis, A. and Tintorè, J., 1999. The role of straits and channels in understanding the characteristics of Mediterranean circulation. Progr. Oceanogr., 44 : 65-108.

Astraldi, M, Conversano, F., Civitarese, G., Gasparini, G. P., Ribera d'Alcala, M. and Vetrano, A., 2001. Water mass properties and chemical signatures in the central Mediterranean region. J. Mar. Syst., this volume.

Ayoub, N., Le Traon, P.Y. and De Mey, P., 1998. A description of the Mediterranean surface variable circulation from combined ERS-1 and TOPEX/POSEIDON altimetric data. J. Mar. Sys., $18: 3-40$.

Barale, V. and Larkin, D., 1998. Optical remote sensing of coastal plumes and run-off in the Mediterranean region. J. Coastal Conservation, $4: 51-58$.

Barale, V. and Zin, I., 2000. Impact of continental margins in the Mediterranean Sea : hints from the surface colour and temperature historical record. J. Coastal Conservation, $6: 5$ 14.

Baretta-Bekker, J.G., Baretta, J.W. and Ebenhöh, W., 1997. Microbial dynamics in the marine ecosystem model ERSEM II with decoupled carbon assimilation and nutrient uptake. J. Sea Res., 38: 195-212.

Beckers, J. M., Rixen M., Brasseur, P., Brankart, J.-M, Elmoussaoui, A., Crépon, M., Herbaut, Ch., Mertel, F., Van Den Berghe, F., Mortier, L., Lascaratos, A., Drakopoulos, P., Korres, G., Pinardi, N., Masetti, E., Castellari, S., Carini, P., Tintore, J., Alvarez, A., Monserrat, S., Parilla, D., Vautard, R. and Speich S., 2001. Model intercomparison in the Mediterranean. The MEDEX simulations of the seasonal cycle. J. Mar. Syst., this volume.

Benkiran, M., de Mey, P. and Ayoub, N., 1997. Comparaison des données altimétriques Topex/Poseidon en Méditerranée avec un modèle de circulation générale. C. R.Acad. Sc., 325: 201-205.

Bethoux, J.P., Gentili, B., Raunet, J. and Tailliez, D., 1990. Warming trend in the western Mediterranean deep water. Nature, 347: 660-662.

Bethoux, J.P., Morin, C. and Gentili, B., 1992. Phosphorous and nitrogen behaviour in the Mediterranean Sea. Deep-Sea Res., 39: 1641-1654.

Bethoux, J.P. and Gentili, B., 1997. Functioning of the Mediterranean Sea: past and present changes related to freshwater input and climate changes. J. Mar. Sys., in press.

Bethoux, J.P., Gentili, B. and Tailliez, D., 1998. Warming and freshwater budget in the Mediterranean since the 1940s, their possible relation to the greenhouse effect. Geophys.Res. Let., 25, 7: 1023-1026.

Boldrin, A., Miserocchi, S., Rabitti, S., Turchetto, M-M., Balboni, V. and Socal, G., 2001. Particulate matter in the Southern Adriatic and Ionian Sea: characterisation and downward fluxes. J. Mar. Syst., this volume.

Cacho, I., Grimalt, J.O., Pelejero, C., Canals, M., Sierro, F.J., Flores, J.A. and Shackleton, N.J., Dansgaard-Oeschger and Heinrich event imprints in the Alboran Sea paleotemperatures. Paleoceanogr., in press.

Cacho, I., Grimalt, J.O. and Canals, M. Response of the western Mediteranean Sea to the rapid climatic variability that occurred during the last 50,000 years. A molecular biomarker approach. J. Mar. Syst., this volume.

Chronis, G., Lykousis, V., Georgopoulos, D., Zervakis, V., Stavrakakis, S. and Poulos, S., 2000. Suspended particulate matter and nepheloid layers in the Southern Margin of the 
Cretan Sea (NE Mediterranean): seasonal distribution and dynamics. Progr. Oceanogr., 46: 163-165.

Crise, A., Allen, J.I., Baretta, J., Crispi, G., Mosetti, R. and Solidoro, C., 1999. The Mediterranean pelagic ecosystem response to physical forcing. Progr. Oceanogr., 44: 219243.

Crispi, G., Crise, A. and Solidoro, C., 2001. Coupled Mediterranean ecomodel of phosphorus and nitrogen and cycles. J. Mar. Syst., this volume.

Danovaro, R., Dinet, A., Duineveld, G. and Tselepides, A., 1999. Benthic response to particulate fluxes in different trophic environments: a comparison between the Gulf of Lions-Catalan Sea (western Mediterranean) and the Cretan Sea (eastern Mediterranean), Progr. Oceanogr., 44: 287-312.

Danovaro, R., Tselepides, A., Otegui, A. and Della Croce, N., 2000. Dynamics of the meiofaunal assemblages on the continental shelf and deep-sea sediments of the South Aegean Sea: relationships with seasonal changes in food supply. Progr. Oceanogr., 46: 367-400.

Della Vedova, B., Foucher, J.P., Pellis, G., Camerlenghi, F. and MEDRIFF Consortium, 1995. Heat flow measurements on the Mediterranean ridge indicate transient processes of heat transfer between sediments and the water column, Rapp. Comm. Int. Mer Mediter., p. 100.

Demirov, E. and Pinardi, N., Simulation of the Mediterranean Sea circulation from 1979 to 1993. Part I : the interannual variability. J. Mar. Syst., this volume.

Diaz, F., Raimbault, P. and Conan, P., 2000. Small-scale study of primary productivity during spring in a Mediterranean coastal area (Gulf of Lions). Cont. Shelf Res, 20: 975-996.

Duarte, C.M., Agusti, S., Kennedy, H. and Vaqué, D., 1999. The Mediterranean climate as a template for Mediterranean marine ecosystems: the example of the northeast Spanish littoral. Progr. Oceanogr., 44: 245-270.

Duineveld, G., Van der Weele, J., Berghuis, E., Witbaard, R. and Tselepides, A., 1999. Spatial differences in benthic activity in the Aegean Sea. $4^{\text {th }}$ MTP-MATER Workshop, Perpignan-France, p. 156.

Dupuis, H., Guérin, C., Weill, A. and Hauser, D., 1999. Heat fluxes by the inertial dissipation method during FETCH. Proc. Symp. Air-Sea Interface, Sydney.

Fabrés, J., Calafat, A., Sanchez-Cabeza, J.A. and Canals, M., 2001. Composition and spatiotemporal variability of particle fluxes in the Western Alboran Gyre, Mediterranean Sea. J. Mar. Syst., this volume.

Flexas, M., Garcia, M. A., Durrieu de Madron, X., Arnau, P. and Canals, M., 2001. Flow variability in the Gulf of Lions during the MATER HFF Experiment (March-May 1997). J. Mar. Syst., this volume.

Gacic, M., Kovacevic, V., Manca, B., Papageorgiou, E., Poulain, P.M., Scarazzato, P; and Vetrano, A., 1996. Thermohaline properties and circulation in the Strait of Otranto. In: F. Briand (Editor), Dynamics of Mediterranean Straits and Channels. Bull. Inst. Oceanogr., sp. Issue 17, 2: 117-145.

Gacic, M., Civitarese, G. and Ursella, L., 1999. Spatial and seasonal variability of water and biogeochemical fluxes in the Adriatic Sea. In: P. Malanotte-Rizzoli and V.N. Eremeev (Editors), The Eastern Mediterranean as a laboratory basin for the assessment of contrasting ecosystems, Kluwer Acad. Publ. (NL), pp. 335-357.

Garrett, C., Outerbridge, R. and Thompson, K., 1993. Interannual variability in Mediterranean Heat and Bouyancy Fluxes. J. Climate, 6: 900-910.

Giordani, P., Hammond, D., Berelson, W.M., Montanari, G., Poletti, R., Milandri, A., Frignani, M., Langone, L., Ravaioli, M., Rovatti, G. and Rabbi, E., 1992. Benthic fluxes 
and nutrient budgets for sediments in the Norhern Adriatic Sea: burial and recycling efficiencies. Sci. Tot. Environ. Suppl.: 251-275.

Giordani, P., Helder, W., Koning, E., Miserocchi, S., Danovaro, R. and Malaguti, A., 2001. Gradients of benthic-pelagic coupling and carbon budgets in the Adriatic and Northern Ionian Sea. J. Mar. Syst., this volume.

Gorsky, G., Picheral, M., and Stemmann, L., 2000. Use of the Underwater Video Profiler for the study of aggregate dynamics in the North Mediterranean. Estuar, Coast Shelf Sci., 50: 121-128.

Gorsky, G., Prieur, L., Taupier-Letage, I., Stemmann, L. and Picheral, M., 2001. Large Particulate Matter (LPM) in the Western Mediterranean. I - LPM distribution related to hydrodynamics. J. Mar. Syst., this volume.

Hauser, D., Eymard, L., and Dupuis, H., 1998. Presentation of the FETCH campaign in the Gulf of Lions and its interest for turbulent fluxes estimates at the air-sea interface from in situ and remote sensing observations, Proc. $3^{\text {rd }}$ MTP Workshop, Rhodes.

Heussner, S. and Monaco, A., 1996. The MTP sediment trap experiments: highlights on particle fluxes through the eutrophic and oligotrophic systems of the Mediterranean Sea. Proc. $2^{\text {nd }}$ MTP Workhop, Iraklion, Greece, pp. 233-239.

Ignatiades, L., 1998. The productive and optical status of the oligotrophic waters of the Soouthern Aegean Sea (Cretan Sea), Eastern Mediterranean. J. Plankton Res, 20, 5: 985995.

Klein, B., Roether, W., Manca, B.B., Bregant, D., Beitzel, V., Kovacevich, V. and Lucchetta, A., 1999. The large deep water transient in the Eastern Mediterranean. Deep Sea Res. I, 46: 371-414.

Klein, B., Roether, W., Civitarese, G., Gacic, M., Manca, B.B. and Ribera d'Alcala, M., 2000. Is the Adriatic returning to dominate the production of Esatern Mediterranean Deep Water? Geophys. Res. Letters, 27, 20: 3377-3380.

Larnicol, G., Ayoub, N. and Le Traon, P. Y., 2001. Majors changes of the Mediterranean sea level variability from 7 years of T/P and ERS-1/2 data. J. Mar. Syst., this volume.

Levy, M., Memery, L. and Madec, G., 1999. The onset of the spring bloom in the MEDOC area: mesoscale spatial variability. Deep-Sea Res., in press.

Lampadariou, N. and Tselepides, A. 1999. Spatial and temporal variability of meiofaunal communities at sites of contrasting productivity in the deep Aegean Sea. Proc. $4^{\text {th }}$ MTPMATER Workshop, Perpignan-France, p.176.

Larnicol, G., Le Traon, P.Y., Ayoub, N. and de Mey, P., 1995. Sea level variability in the Mediterranean Sea from two years of Topex/Poseidon data. J. Geophys. Res., 100: 2516325177.

Lascaratos, A., Roether, W., Nittis, K. and Klein, B., 1999. Recent changes in deep water formation and spreading in the eastern Mediterranean Sea: a review. Progr. Oceanogr, 44: 5-36.

Levy, M., Memery, L. and Madec, G., 1998. The onset of a bloom after deep winter convection in the northwest Mediterranean Sea: mesoscale process study with a primitive equation model. J. Mar. Syst., 16: 7-21.

Loukos, H. Memery, L. and Mortier, L., 1999. Biogeochemical signature of Algerian eddies. Preliminary results from a modeling study. $4^{\text {th }}$ MTP-MATER Workshop, PerpignanFrance, p. 49.

Olivier, F. and Memery, L., 1999. Fertilising effect of a permanent quasi geostrophic front : a numerical study of the Almeria-Oran Front. $4^{\text {th }}$ MTP-MATER Workshop, PerpignanFrance, p. 134.

Lykousis, V., Theocharis, A., Krassakopoulou, E., Price, B., Pates, J., Christaki, U., Giannakouru, A., Van Wambeke, F., Christou, E., Siokou, I., Zervoudaki, S., GotsisStretas, O., Pagou, K., Bouloubassi, I., Polychronaki, T., Podoras, I., Lampadariou, N., 
Marrale, D. and Masqué, P., 1999. MTP II-MATER transmediterranean cruise (June 99), Proc. $4^{\text {th }}$ MTP Workshop, Perpignan, France, p.141.

Lykousis, V., Chronis, G., Tselepides, A., Siokou-fragou, I., Van Wambeke, F., Danovaro, R., Stravakakis, S., Duineveld, G., Georgopoulos, D., Ignadiades, L., Voutsinou-Taliadouri, F. and Souvermezoglou, E., 2001. Major ouputs of the recent multidisciplinary biogeochemical reseraches in the Aegean Sea. J. Mar. Syst., this volume.

Maillard, C., Balopoulos, E., Giorgetti, A., Fichaut, M., Iona, S., Larour, M., Latrouite, A., Manca, B., Maudire, G., Nicolas, P. and Sanchez-Cabeza, J. -A., 2001. MTPII-MATER Database: Integrated multidisciplinary data set produced from 1996 to 1999 in the Mediterranean Sea, Sources, Quality Assurance and High Technology Software Tools for data checking and retrieval. J. Mar. Syst., this volume.

Manca, B., Kovacevic, V., Gacic, M. and Viezzoli, D., 2001. Dense water formation in the southern Adriatic Sea and interaction with the Ionian Sea in the period 1997-1999. J. Mar. Syst., this volume.

MERMAIDS, 1998. Mediterranean eddy resolving and interdisciplinary studies. In $\mathrm{N}$. Pinardi, \& W. Roether (Editors), J. Mar. Syst., sp. issue: 1-312.

Millot, C., 1985. Some features of the Algerian Current. J. Geophys. Res., 90: 7169-7176.

Monaco, A., Durrieu de Madron, X., Radakovitch, O., Heussner, S. and Carbonne, J., 1999. Origin and variability of downward biogeochemical fluxes on the Rhone continental margin (NW Mediterranean). Deep Sea Res., I, 46: 1483-1511.

Moutin, T. and Raimbault, P., 2001. Primary production, carbon export and nutrients availability in western and eastern Mediterranean Sea in early summer 1996 (MINOS cruise). J. Mar. Syst., this volume.

Myers, P.G. and Haines K. Modelling the paleo-circulation of the Mediterranean: Part II. The last glacial. Paleoceanogr, in press.

Myers, P.G. and Haines K., 2000. Seasonal and interannual variability in a model of the Mediterranean under derived flux forcing. J. Phys. Oceanogr., 30: 1069-1082.

Pierini, S., Gervasio, L., Rubino, A., Simioli, A. and Zambianchi, E., 1997. Modelling studies on the circulation of the Western Mediterranean Sea and the Straits of Sicily. Proc. Int. Conf. MAST, Roma, Italy.

Pinardi, N., Korres, G., Lascaratsos, A., Stanev, E. and Roussenov, V., 1997. The simulation of the interannual variability of the Mediterranean Sea upper ocean circulation. Geophys. Res. Let., 24, 4: 425-428.

Pinardi, N. and Mosetti, E., 2000. Variability of the large-scale general circulation of the Mediterranean Sea from observations and modelling: a review. Palaeogeogr, Palaeoclimatol, Palaeoecol., 158: 153-174.

Price, N.B., Brand, T., Pates, J.M., Mowbray, S., Theocharis, A., Civitarese, G., Miserocchi, S., Heussner, S. and Lindsay, F., 1999. Horizontal distributions of biogenic and lithogenic elements of suspended particulate matter in the Mediterranean Sea. Progr. Oceanogr., 44: 191-218.

Reich, M. and Send, U., 1999. Deep float observations in the Western Mediterranean basin. Proc. $4^{\text {th }}$ MTP Workshop, Perpignan, France, p. 54.

Riera, M., Fernandez, V., Lopez-Juradp, J.L., Font, J. and Tintoré, J., 1999. Interannual variability of the north-south exchanges in the Western Mediterranean in relation with the presence of winter intermediate water. Proc. $4^{\text {th }}$ MTP Workshop, Perpignan, France, p. 83.

Roether, W., Manca, B.B., Klein, B., Bregant, D., Georgopoulos, D., Beitzel, V., Kovacevic, V. and Luchetta, A., 1996. Recent Changes in Eastern Mediterranean Deep Waters, Science, 271: 333-335.

Roether, W., Klein, B., Beitzel, V. and Manca, B., 1998. Property distributions and transienttracer ages in Levantine intermediate water in the Eastern Mediterranean. J. Mar. Syst., 18: 71-87. 
Ruiz, S., Font, J., Emelianov, M., Isern-Fontanet, J., Millot, C. and Salas J., 2001. Deep structure of an open sea eddy in the Algerial basin. J. Mar. Syst., this volume.

Sanchez-Cabeza, J. A., Ortega, M. and Merino, J., 2001. Long-term box modelling of ${ }^{137} \mathrm{Cs}$ in the Mediterranean Sea. J. Mar. Syst., this volume.

Sempéré, R., Van Wambeke, F., Panagiotopoulos, C., Souvemerzoglou, K. and Bianchi, M., 2001. Total organic carbon dynamic in Aegean Sea. J. Mar. Syst., this volume.

Send, U., Font, J., Krahmann, G., Millot, C., Rhein, M. and Tontoré, J., 1999. Recent advances in observing the physical oceanography of the western Mediterranean Sea. Progr. Oceanogr., 44: 37-64.

Siokou-Frangou, I., Bianchi, M., Christaki, U., Christou E., Giannakourou, A., Gotsis, O., Ignatides, L., Pagou, K., Pitta, P., Psarra, S., Souvermezoglou, E., Van Wambeke, F. and Zervakis, V., 2001. Organic carbon partitioning and carbon flow along a gradient of oligitrophy in the Aegean sea (Mediterranean Sea). J. Mar. Syst., this volume.

Stratford K. and Haines, K., 2001. Modelling changes in the Mediterranean thermohaline circulation, 1987-1995. J. Mar. Syst., this volume.

Taupier-Letage, I. and Millot, C., 1988. Surface circulation in the Algerian Basin during 1984. Oceanol. Acta, sp. 9: 119-131.

Taupier-Letage, I., Puillat, I., Millot, C. and Albérola, C., 1999. Algerian eddies and chlorophyll : how close is the link? (Biological response associated to mesoscale eddies in the Algerian Basin during the Elisa operation - July 1997/1998). $4^{\text {th }}$ MTP-MATER Workshop, Perpignan-France, p. 47.

Testor, P., Gascard, J.C. and Lourenço, A., 1999. Large and mesoscales circulation in the Northwestern Mediterranean. Proc. $4^{\text {th }}$ MTP Workshop, Perpignan, France, p. 25.

Theocharis, A., Nittis, K., Kontoyiannis, H., Papageorgiou, E. and Balopoulos, E., 1999. Climatic changes in the Aegean Sea influence the Eastern Mediterranean thermohaline circulation (1986-1997). Geophys. Res. Letters, 26, 11: 1617-1620.

Theocharis, A., Klein, B., Nittis, K. and Roether, W., 2001. Evolution and status of the eastern mediterranean transient (1997-99). J. Mar. Syst., this volume.

Thingstad, T.F. abd Rassoulzadegan, F., 1995. Nutrient limitation, microbial food webs and biological C-pumps: suggested interactions in a P-limited Mediterranean. Mar. Ecol. Prog. Ser., 117: 299-306.

Tholosan, O. and Bianchi, A., 1998. Bacterial distribution and activity at the water-sediment boundary layer on the NW Mediterranean margin. Mar. Ecol. Prog. Ser., 168: 273-283.

Tselepides, A., Papadopoulou, K., Podaras, D. and Koutsoubas, D. 1999. Benthic community structures in areas of contrasting productivity in the Aegean Sea. $4^{\text {th }}$ MTP-MATER Workshop, Perpignan-France, p. 155.

Turley, C.M., 1999. The changing Mediterranean Sea - a sensitive ecosystem? Progr. Oceanogr, 44: 387-400.

Turley, C., Bianchi, M., Christaki, U., Conan, P., Harris, J., Psarra, S., Ruddy, G., Stutt, E.D., Tselepides, A., and Van Wambeke, F., 2000. Relationships between primary producers and bacteria in an oligotrophic sea - the Mediterranean - and biogeochemical implications. Mar. Ecol. Prog. Ser., 193: 11-18.

Valette, F., 1999. Interactions between research and policy. From wishes to realities, in a changing world. Progr. Oceanogr., 44: 433-456.

Van Wambeke, F., Heussner, S., Diaz, F., Raimbault, P. and Conan, P., 2001. Small-scale variability in the coupling/decoupling of bacteria, phytoplankton and organic carbon fluxes along the continental margin of the Gulf of Lions, North western Mediterranean Sea. J. Mar. Syst., this volume.

Zavatarelli, M., Baretta, J.W., Baretta-Bekker, J.G. and Pinardi, N., 2000. The dynamics of the Adriatic Sea ecosystem. An idealized model study. Deep-Sea Res., 47: 937-970. 
Zavatarelli, M., 1999. Mediterranena Sea multiscale variability and environmental management issues: a scientific perspective. Progr. Oceanogr., 44: 401-409. 
The Mediterranean Targeted Project MATER - A multiscale approach of the variability of a marine system - Overview

\section{A. Monaco, S. Peruzzi}

\section{Figure captions}

Fig. 1. Matrix-like organisation of the MATER programme.

- Horizontally, the scientific topics called Research Tasks (RT), from RT I to RT VII (from physics of the water masses to marine ecosystems), with their RT representatives,

- Vertically, the at sea strategies and tools used to implement the scientific topics and called Workpackages (WP) ; the Workpackages include : the different physiographical areas of the Mediterranean, western, central and eastern basins (WP 3, 4, 5) and modelling activities (WP 1 \& 6). The Data Management represents another task, receiving and managing the data from the national data centers working in the three Mediterranean basins

- The Steering Committee is formed by the WP and RT representatives, the Data Manager, the Scientific Coordinator, the project's Manager and the EC officer

Fig. 2. Example of the spatial distribution of the measurements performed during MATER project (3141 CTD stations). This distribution shows the most investigated areas of the programme (from CD-Rom MATER data set 1996-1999). 


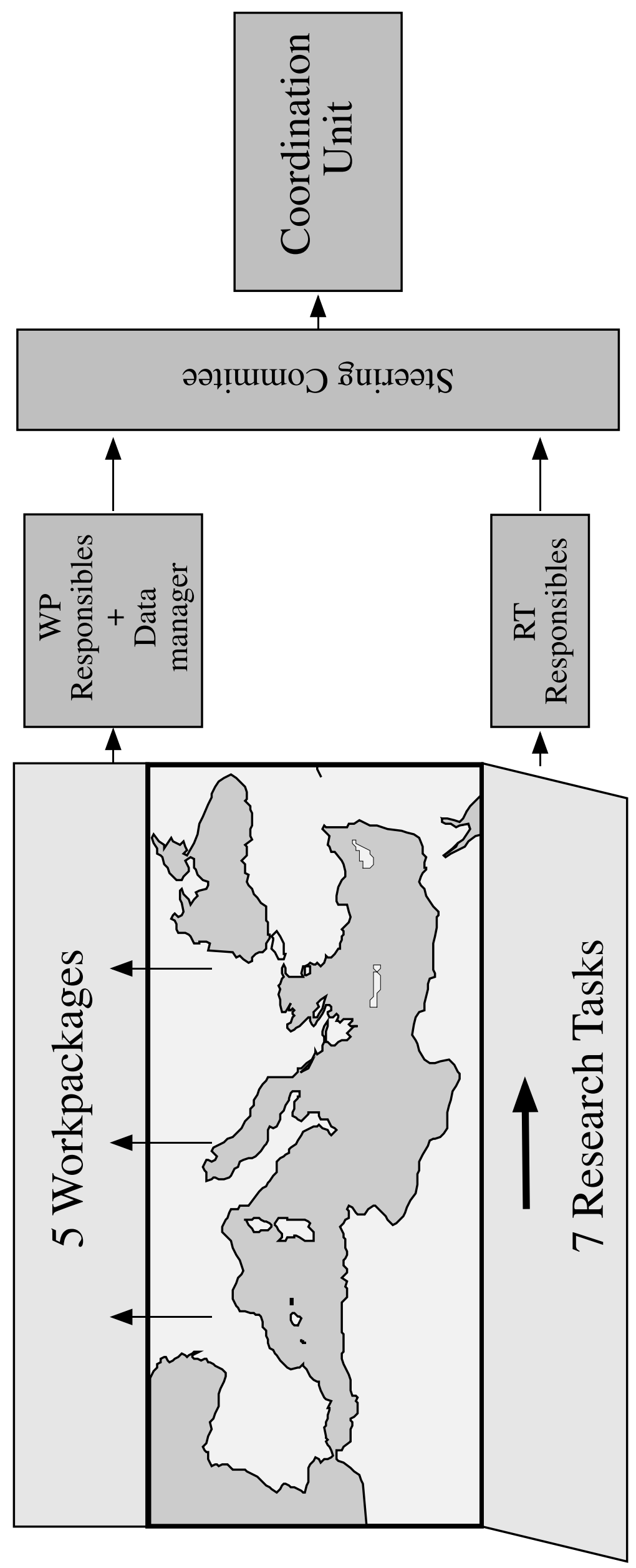




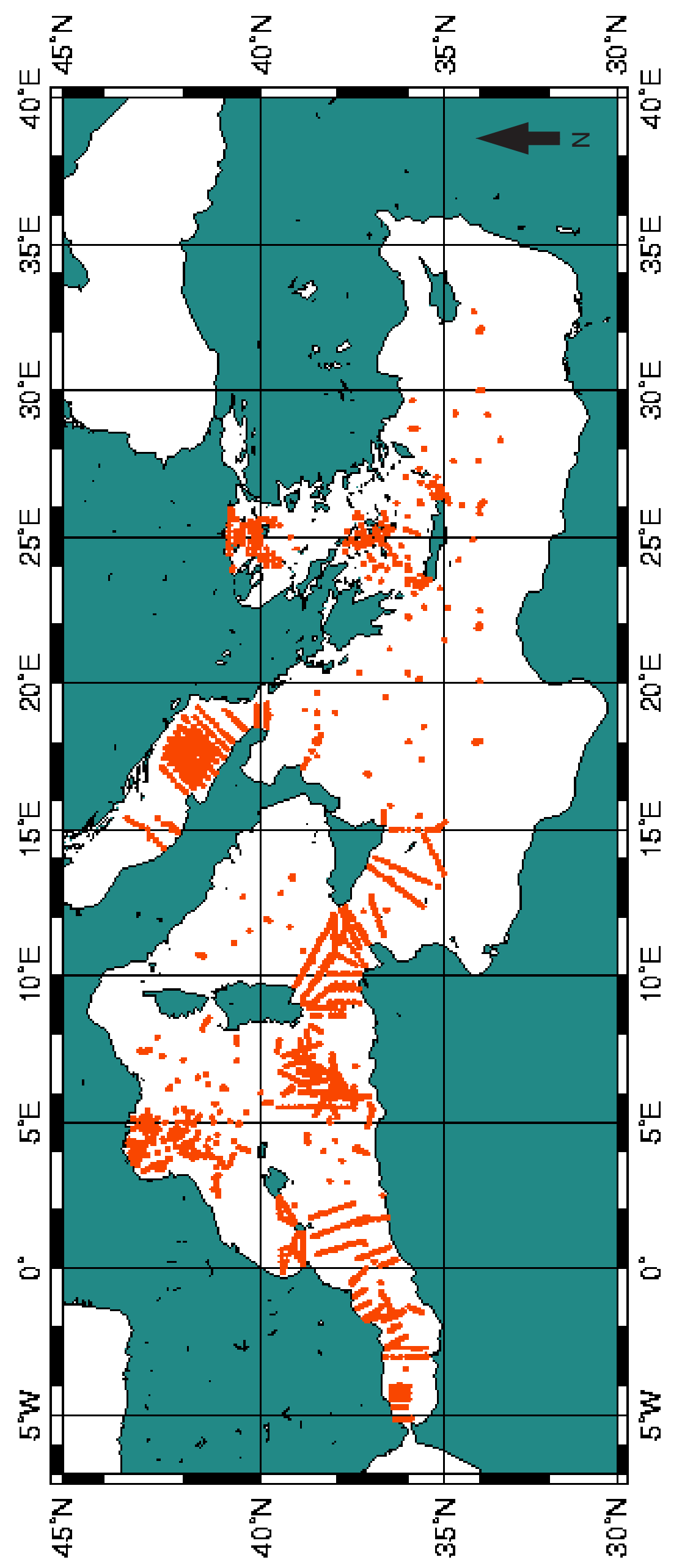

